\title{
EFFECTS OF ENGLISH INSTRUCTION USING THE FLIPPED CLASSROOM CONCEPT TO DEVELOP SPEAKING SKILL OF GRADES 1 - 3 IN COVID-19 SITUATION
}

\author{
Author \\ Warissara Wongsrikaew ${ }^{1}$, Lilis Kartika Dewi ${ }^{2}$, Wanida Simpol ${ }^{3}$ \\ Huaiduanoi School, Nonghin, Loei 42190, Thailand \\ Universitas Muhammadiyah Gresik, Indonesia \\ Loei Primary Educational Service Area Office 2, Wangsaphung Loei \\ Waritsara5793@gmail.com
}

\begin{abstract}
This research is conducted with Indonesian students. The objectives of the research were: (1) to develop and verify the efficiency of the Flipped Classroom Plan for Grades 1 - 3 (2) to examine the effectiveness of the Flipped Classroom Plan for Grade 1 - 3 Students (3) To study the learning achievement of grades 1 - 3 students who studied using a flipped classroom learning activity plan in the situation of COVID-19, the researcher used the research process in the first semester of the academic year. 2021 Data was collected between July and October 2021 . Tools used include Plan to organize learning activities in a flipped classroom, 10 plans, 10 hours, with speaking skill assessment. Data were analysed using basic statistics such as frequency, percentage, mean, standard deviation. average efficiency performance index Effectiveness Index and relative development scores.

The results of the research on the effects of English instruction using the flipped classroom concept to develop speaking skill of Grades 1 - 3 in COVID-19 situation. The results of the research were summarized as follows.
\end{abstract}

Keyword: Speaking skill, Flipped Classroom, COVID-19

\section{Introduction}

English is an important language and it is necessary to learn to communicate with the people of the world and it is important for further education at higher levels and in work life. People in each country must communicate with each other in All aspects, whether it is economic, social, political, government, education, art, culture, tradition, tourism, and others. using English as the medium English is humanity's lingua franca for communicating with people of different languages and cultures, so it is important to use English as the primary language in daily life. English is a tool in communication, education, seeking knowledge occupation building understanding of culture Various visions of the global community bring friendship and cooperation with various countries Help develop learners to understand themselves and others, understand differences in language and culture, traditions, thinking, society, economy, politics, and governance, as well as gain access to a wide range of knowledge more easily. The Ministry of 
Education has given importance to foreign languages as basic learning materials. It has been prescribed to study throughout the core curriculum of basic education, which is English. which aims to enable learners to use foreign languages to communicate in various situations (Ministry of Education. 2008: 220-221) We are living through a period of rapid change in an increasingly globalized environment, to which education systems need to adapt, especially students who need to be more knowledgeable and skilful. Additionally, they need to practice through various in-reallife situations in accordance with guidelines for education which emphasize the importance of learning English as follows;

Speaking skills allow us to communicate effectively and give us the ability to convey information verbally and in a way that the listener can understand. Since Thai people are not native English speakers and don't generally use English to communicate in their daily life, speaking English seems quite a difficult task due to incorrect accent or pronunciation. Nevertheless, if students practice often, they will be able to communicate correctly even though they might not pronounce it in the perfect way. Students should also emphasize on how to communicate in more meaningful way because other than pronunciation and accent, there are also other important factors such as, vocabulary, grammar, including body language that can help them to communicate better. Students can practice using the recording that come with the textbook or reading news in English for more exposure, especially when the most important factor that Thai people cannot speak English is the lack of opportunity to do so.

\section{Method}

Researching Developing students' speaking skill Grades 1 - 3 in the situation of Covid 19 by applying the concept of the classroom upside down. The researcher proceeded with the following steps:

1. Target group

2. Research tools

3. Creation and quality of tools

4. Data collection

5. Data manipulation and data analysis

6. Data analysis conducting research

Because of this research, the researcher proceeded according to the research framework by studying the problem conditions and background information. Learning management practice related to the development of students' students' speaking skill Grades 1 - 3 situation of Covid 19 by applying the concept of the classroom upside down. study course Concepts and theories about learning activities based on the inverse classroom concept in English subjects, using the collected data to design the learning activities process and presenting them to research advisors and experts. to check the quality of the learning process as to the validity, comprehensiveness, and feasibility to improve students' speaking skill Grades 1 - 3 In the situation of Covid 19 by applying the concept of the classroom inverted as well as the students' basic needs and abilities in a learning 
context. To connect with the framework of the activities of learning English subjects in this research for students to be successful by There are six steps as follows.

\section{a. Participants}

In this research, the target group consisted of 14 students in Grades $1-3$ students at Huaiduanoi School, Nong Hin District, Loei Province, Loei Primly Educational Service Area Office 2, totaling 14 students in the first semester of the academic year 2021. Purposive Sampling

Research scope

The researcher has defined the scope of research as follows.

1 ). The scope of content used in the research is the content according to the core curriculum of basic education, B.E. 2551 (2008), the subject group for learning foreign languages (English), grades $1-3$, semester 1 of the academic year 2021 to prepare a plan. A total of 4 learning plans were organized for 10 hours in total.

$\begin{array}{ll}\text { Unit1: My Friends } & 2 \text { plan, } 2 \text { hours } \\ \text { Unit2: My Family } & 2 \text { plans, } 2 \text { hours } \\ \text { Unit3: You and me } & 3 \text { plan, } 3 \text { hours } \\ \text { Unit4: My classroom } & 3 \text { plan, } 3 \text { hours }\end{array}$

2). Scope of the target group

The scope of the research target group consists of the target groups as follows: Grades 1 - 3 students at Huaiduanoi School, Nong Hin District, Loei Province, under the Office of Elementary Education Service Area 2, in the first semester of the academic year 2021, used for the development of speaking skill of students in Prathomsuksa 1 - 3 in the situation of COVID-19 by applying the concept of an inverted classroom to use in online learning management. In various applications to guide the development and application of learning management, observe the behavior of learning management in one English subject classroom of 30 students, which were obtained by random sampling (Purposive Sampling).

3). Scope of learning model Flipped Classroom in combination with online learning activities

The researcher will use the information that appears from the study to analyze. synthesized in the beginning Let's design learning management to be detailed in the process of learning management in English. Grades 1 - 3 for learning management for learners to achieve the ability to learn English and to develop students' English students' English speaking skills of Grade 1 - 3 in the situation of Covid 19 by applying the concept of an inverted classroom in online learning management. in various applications The Huaiduanoi School has taught online through the application of Line meeting application, TikTok application, and Youtube to improve the ability to teach English to have better academic achievement.

\section{Time boundaries}


The researcher will spend time researching in the first semester of the academic year 2021 from July 2021 to September 2021 by organizing learning activities by foreign language learning subjects. by applying the concept of an inverted classroom in the management of online learning. in various applications by selecting content from the scope (Themes), Topics, Sub-Topics, selected from 4 different learning units, 10 hours.

\section{Variables studied}

5.1 Primary variables or independent variables 10 plans for learning management using the concept of a reverse classroom

5.2 Variables according to speaking skill assessment of Grades 1 - 3 students in the situation of covid 19 By applying the concept of the Flipped Classroom.

\section{B. Measures}

Innovative design to develop learning management processes by applying the concept of the inverted classroom to develop students' speaking skill of Grades 1 - 3 students in the situation of COVID-19 by studying documents and research on learning activities by applying the concept of the classroom upside down to obtain knowledge of the theory related to the learning activities used in this research It was found that the content and components of the learning activities that covered the important issues in the learning activities should consist of learning activities format Characteristics of learning activities The process of organizing learning activities and the role of students and teachers and analyzing the concept of the classroom upside down. The process of organizing learning activities to determine the steps in the development of learning activities.

\section{Procedure and design}

The results of the analysis of the steps by applying the concept of the inverted classroom consisted of the following steps:

Before teaching (outside the classroom)

Step 1 (Plan) Make a plan. Teachers design lesson plans. set teaching objectives Selection of teaching media and supplementary activities that are appropriate for the learner's age, classroom, and school context.

Step 2 (Select strategies, technology media, and materials) Record and prepare video tutorials. Teachers may record their teaching. Or use the service from teaching videos that contain complete lesson content according to the indicators, methods, technologies, media, and equipment.

Step 3 (Share) Step Share Teachers share teaching videos. send to students and explain that the content of the video will be discussed in the classroom (At this stage, the teacher may create an activity or hand out pre-class quizzes for students to try before teaching in the classroom)

In the classroom

Step 4 (Knowledge Sharing) Exchange to encourage interaction between teachers. Teachers give children the opportunity to discuss, exchange, and ask questions based on the content that has been studied in the video. to develop analytical thinking skills and communication

Step 5 (Group work) Divide the groups to achieve the planned results. Teachers divide groups so that students can work together. on the topic assigned by the teacher or help each other choose a topic to work for to develop creative thinking and collaboration skills. 
(In the meantime, teachers can observe to assess students during the presentation. Teachers may assign them as exercises or worksheets.)

Step 6 (Discussion) group together again. to present the group's work Open a platform for friends to share their opinions and ask questions.

\section{Data analysis}

Data analysis students

1. Part 1 Assessment of the Flipped Classroom Learning Management Plan for grades 1- 3

2. Part 2 The results of the review of the effectiveness of the inverted classroom learning management plan. (Flipped Classroom) for Grades 1 - 3 students

3. Part 3 The results of a study on the speaking skill of grades 1 - 3 students who studied using an organizational plan

Flipped Classroom Learning in the COVID-19 Situation

The researcher studied the problem condition and basic information to develop English language proficiency skills to enhance learning achievement in conjunction with the inverted classroom concept of grades 1 - 3 students. It was found that the context of learning management English in Huaiduanoi School Students still have problems in speaking at the level that they need to improve or improve. The researcher studied the concept of applying the concept of Flipped classrooms to improve English language achievement. For students to achieve success in learning management design, 10 plans, 10 hours by dividing all content into 4 learning units.

Data analysis results.

Part 1 Assessment of the Flipped Classroom Management Plan for Grades 1 - 3 students by 3 experts

Table 4. Plan evaluation results of learning management plans by applying the flipped classroom concept to improve students' speaking skill of grades 1 - 3 in the situation of COVID19 by 3 experts assessing the quality and suitability of the plan. and the results are shown in Table 4.

\begin{tabular}{c|c|c|lc}
\hline \hline Lesson Plan & $\begin{array}{c}\text { Total average } \\
(\overline{\mathrm{x}})\end{array}$ & $\begin{array}{c}\text { Standard } \\
\text { Deviation }(\mathrm{S} . \mathrm{D})\end{array}$ & \multicolumn{2}{|c}{ Interpret results } \\
\hline 1 & 4.0 & 1.00 & $\begin{array}{l}\text { Very good quality and } \\
\text { suitable }\end{array}$ \\
\hline 2 & 4.6 & 0.57 & $\begin{array}{l}\text { Very good quality and } \\
\text { suitable }\end{array}$ \\
\hline 3 & 4.6 & 1.00 & $\begin{array}{l}\text { Very good quality and } \\
\text { suitable }\end{array}$ \\
\hline 4 & 4.6 & 0.57 & $\begin{array}{l}\text { Very good quality and } \\
\text { suitable }\end{array}$ \\
\hline 5 & 4.6 & 0.57 & $\begin{array}{l}\text { Very good quality and } \\
\text { suitable }\end{array}$ \\
\hline 6 & 4.1 & 0.57 & Very good quality and \\
\hline
\end{tabular}




\begin{tabular}{c|c|c|lc}
\hline & & & suitable & \\
\hline 7 & 3.6 & 0.57 & $\begin{array}{l}\text { Very good quality and } \\
\text { suitable }\end{array}$ \\
\hline 8 & 3.9 & 0.57 & $\begin{array}{l}\text { Very good quality and } \\
\text { suitable }\end{array}$ \\
\hline 9 & 4.0 & 0.57 & $\begin{array}{l}\text { Very good quality and } \\
\text { suitable }\end{array}$ \\
\hline 10 & 5 & 0.57 & $\begin{array}{l}\text { Very good quality and } \\
\text { suitable }\end{array}$ \\
\hline Overall & 4.36 & 0.33 & $\begin{array}{l}\text { Very good quality and } \\
\text { suitable }\end{array}$ \\
\hline
\end{tabular}

From Table 4, it was found that the assessment results of the learning management plan by applying the flipped classroom concept to improve speaking skill of grades 1 - 3 students in the COVID-19 situation were conducted by experts. The mean per plan ranged from $3.6-5$ and the overall average was 4.36 and compared with the quality and suitability criteria. According to the preliminary quality level conditions, it was found that the learning management plan applied the concept of flipped classrooms to improve speaking skill. Primary school grades 1 - 3 in the situation of COVID-19, the quality and appropriateness of each plan are at the highest level. and overall assessment results All plans are at a high level $(\overline{\mathrm{x}}=4.36$, S.D. $=0.33)$.

Part 2 The results of the review of the effectiveness of the Flipped Classroom Plan for Grade 6 students who meet the criteria of $75 / 75$.

The researcher examined the effectiveness of the learning management plan. It was calculated from the scores of assessment of learning behavior during class, assessment of worksheets, and pre-study and post-study tests. The results are shown in the following table.

Table 5 Results of the review of the efficiency of the Flipped Classroom Plan for Grade 6 students

\begin{tabular}{|c|c|c|c|}
\hline $\begin{array}{l}\text { Activity / } \\
\text { Score }\end{array}$ & $\begin{array}{c}\text { Full } \\
\text { Score }\end{array}$ & $\begin{array}{l}\text { Average } \\
\text { Score }\end{array}$ & Percent \\
\hline Activity 1 & 10 & 5.93 & 59.30 \\
\hline Activity 2 & 10 & 7.14 & 71.40 \\
\hline Activity 3 & 10 & 7.07 & 70.70 \\
\hline Activity 4 & 10 & 7.71 & 77.10 \\
\hline Activity 5 & 10 & 8.00 & 80.00 \\
\hline Activity 6 & 10 & 7.50 & 75.00 \\
\hline Activity 7 & 10 & 7.86 & 78.60 \\
\hline Activity 8 & 10 & 7.79 & 77.90 \\
\hline Activity 9 & 10 & 8.00 & 80.00 \\
\hline Activity 10 & 10 & 8.07 & 80.07 \\
\hline \multicolumn{2}{|c|}{ Total average } & 8.07 & \\
\hline \multicolumn{3}{|c|}{ E1 } & 75.07 \\
\hline
\end{tabular}




\begin{tabular}{|c|c|c|c|}
\hline $\begin{array}{c}\text { Activity / } \\
\text { Score }\end{array}$ & $\begin{array}{c}\text { Full } \\
\text { Score }\end{array}$ & $\begin{array}{c}\text { Average } \\
\text { Score }\end{array}$ & Percent \\
\hline Post-Test & 10 & 7.53 & 75.30 \\
\hline \multicolumn{3}{|c|}{ E2 } & 80.71 \\
\hline
\end{tabular}

From Table 5, it was found that the results of the review of the efficiency of the Flipped Classroom Plan for Grades 1 - 3 students had the process efficiency value (E1) of 75.07, the efficiency of the result (E2) was 80.71 . The efficiency (E1/E2) was $75.07 / 80.17$, higher than the set threshold of $75 / 75$.

Table 6 Effectiveness Index of Flipped Classroom Learning Management Plan for Grades 1 - 3 Students $(\mathrm{N}=14)$

\begin{tabular}{|c|c|c|}
\hline $\begin{array}{l}\text { Total scores before exams } \\
\text { for all rooms } \\
\text { (Full score 10) }\end{array}$ & $\begin{array}{l}\text { The total score after the examination } \\
\text { of the whole room } \\
\text { (Full score 10) }\end{array}$ & $\begin{array}{c}\text { Effectiveness Index } \\
\text { (E.I.) }\end{array}$ \\
\hline 83 & 113 & 52.6315 \\
\hline
\end{tabular}

From Table 6, it was found that the effective index of the Flipped Classroom Plan for Grades 1 - 3 students $(\mathrm{N}=14)$ was applied to the Flipped Classroom concept to improve their speaking skill. Learning English of Grades 1 - 3 students in the situation of COVID-19 by the Effectiveness Index. The overall average was 52.6315.

Part 3 Study results of learning achievement of grades 1 - 3 students who study using a flipped classroom learning management plan in the situation of COVID-19

\subsection{The development of students' speaking skill scores}

The development of speaking skill scores of grades 1 - 3 students, using the relative development score analysis according to Sirichai Kanchanawasi's formula (2009). The evaluation criteria for development scores were as follows:

Development Score (Percent) Meaning

76-100 has a very high level of development.

51-75 has a high level of development.

26-50 has an intermediate level of development

1-25 have early development

Under-0 no improvement

The results of the analysis of speaking skill assessment scores of grades 1-3 students are shown in the following table.

Table 7 Relative Development Scores of speaking skill assessment of Grade 1 - 3 Students in the COVID-19 Situation Using the Inverted Classroom Concept.

\begin{tabular}{|c|c|c|c|c|}
\hline People & Before & After & $\begin{array}{c}\text { percentage } \\
\text { improvement }\end{array}$ & development level \\
\hline 1 & 5 & 7 & 40.00 & high \\
\hline
\end{tabular}




\begin{tabular}{|c|c|c|c|c|}
\hline People & Before & After & $\begin{array}{c}\text { percentage } \\
\text { improvement }\end{array}$ & development level \\
\hline 2 & 6 & 8 & 50.00 & high \\
\hline 3 & 6 & 8 & 50.00 & high \\
\hline 4 & 7 & 9 & 66.66 & Very high \\
\hline 5 & 7 & 9 & 66.66 & Very high \\
\hline 6 & 6 & 8 & 50.00 & high \\
\hline 7 & 5 & 6 & 20.00 & high \\
\hline 8 & 5 & 7 & 40.00 & Very high \\
\hline 9 & 5 & 7 & 40.00 & Very high \\
\hline 10 & 6 & 8 & 50.00 & Very high \\
\hline 11 & 6 & 8 & 50.00 & Very high \\
\hline 12 & 7 & 9 & 66.66 & Very high \\
\hline 13 & 5 & 9 & 80.00 & very high \\
\hline 14 & 7 & 10 & 100 & Very high \\
\hline Average & $\mathbf{5 . 9 2}$ & $\mathbf{8 . 0 7}$ & $\mathbf{5 4 . 9 9}$ & Very high \\
\hline Percent & $\mathbf{5 9 . 2 8}$ & $\mathbf{8 0 . 7 1}$ & & \\
\hline & & & & \\
\hline
\end{tabular}

From Table 7, the relative improvement scores of speaking skill assessment of Grades 1-3 students who studied using a flipped classroom learning plan in the situation of COVID-19, it was found that the percentage of scores before studying was equal to 59.28 The percentage of the score after school was 80.71 and the percentage development was 54.99 The overall development level of the criteria was very high.

Table 8 summarizes the results of the analysis of the relative development scores of speaking skill of Grades 1 - 3 students who studied using the flipped classroom learning management plan in the situation of COVID-19.

\begin{tabular}{|c|c|c|c|c|c|}
\hline \multicolumn{5}{|c|}{ Number of students classified by level of development } & \multirow{2}{*}{ combine } \\
\cline { 1 - 5 } Very high & high & middle & early & $\begin{array}{c}\text { no } \\
\text { development }\end{array}$ & \\
\hline 9 & 5 & 0 & 0 & 0 & 14 \\
\hline
\end{tabular}

From Table 8, the relative improvement scores of speaking skill of grades 1 - 3 students who studied using the flipped classroom learning management plan in the Covid-19 situation found that 9 students showed a very high improvement. with a high level of development of 5 people

\section{Results}

In doing this research is joint research with Indonesian students. The objectives of the research were: (1) to develop and verify the efficiency of the Flipped Classroom Plan for Grades 
1 - 3 (2) to examine the effectiveness of the Flipped Classroom Plan for Grade 1 - 3 Students (3) To study the learning achievement of grades $1-3$ students who studied using a flipped classroom learning activity plan in the situation of COVID-19, the researcher used the research process in the first semester of the academic year. 2021 Data was collected between July and October 2021. Tools used include Plan to organize learning activities in a flipped classroom, 10 plans, 10 hours, with speaking skill assessment. Data were analysed using basic statistics such as frequency, percentage, mean, standard deviation. average efficiency performance index Effectiveness Index and relative development scores the results of the research can be summarized as follows: Summary of research results.

2. The results of the study on the effectiveness index of the Flipped Classroom Plan for grades 1-3 in the COVID-19 situation students $(\mathrm{N}=14)$ found that the application of the Flipped Classroom concept was used to improve the results. The English language learning achievement of grades 1 - 3 students with an overall average effectiveness index of 0.5263 , indicating that the Flipped Classroom plan helped students achieve a hundred percent higher. 52.63 each

\section{Discussion and conclusion}

From the results of the study on the development of English language proficiency skills to enhance learning speaking skill in conjunction with the use of the flipped classroom concept of Grades 1 - 3 students, there are important issues according to the objectives that should be discussed as follows:

1. The results of the study of the assessment of the learning management plan by applying the flipped classroom concept to improve students' speaking skill assessment. Grades 1 - 3 in the situation of COVID - 19 by experts the mean per plan ranged from $3.6-4.6$ and the overall mean was 4.36 , the standard deviation was 0.33 . The results of the review of the efficiency of the Flipped Classroom Plan for grades 1 - 3 students were: The quality and appropriateness of each learning management plan were at the high to the highest level, and the overview of the results The assessment of all learning management plans and the results of the plan's effectiveness was examined which was at high level $(\overline{\mathrm{x}}=4.36$, S.D. $=0.33)$. The flipped classroom for students in grades 1 - 3 had a process efficiency value (E1) of 75.07, the efficiency of the result (E2) of 80.71, efficiency (E1/E2) of 75.07/80.17 high which had the threshold at 75/75.

The conclusion of the above mentioned results are from the study of the assessment of the learning management plan by applying the flipped classroom concept and 6 steps of learning activities. The flipped classroom concept aims to improve students' knowledge, understanding, analysing skills, ability to connect and integrate background knowledge with the newly acquired knowledge and apply it in practice. Flipped Classroom Concept emphasize learning outside and inside the classroom. It originates from development of learning approach that supports exchange of knowledge and discussion both individually and collectively to achieve learning-by-doing experience in accordance with the students' abilities and interests by using motivational questions to provoke students' thought process in order to apply it in real life situations. This will allow analytical thinking to occur. Mood is also an important factor in every step of learning. Moreover, flipped classroom concept's learning activities also emphasizes on letting the students learn by doing. They can learn at home and submit homework at school. Application is a good motivator for students and can hold their interests better when compared with learning by remembering. Teachers are encouraged to create learning activities for students that allow them to relate with real life situations, provide techniques for students to help them remember and act as a coach 
giving out advice and encourage students to think critically by doing Q\&A. Teachers are also encouraged to instruct students to make at least 1 question per student from the videos they have watched from home and use the time from the beginning to the class to discuss and exchange questions and answers in class or through online platform such as Facebook or Line. Teachers could make a question first to draw their attention. Most importantly, teachers must review their learning progress closely and often. If the students have an understanding of the subject, then teachers can start the next lesson which is in accordance with (Bergmann and Sams, 2012) who noted that the flipped class concept is 1) a learning approach that changes from learning in the classroom to learning anywhere 2) allows the most effective use of the time in the classroom to get the better learning achievement and 3) allows student to learn more effectively by doing preclass and post-class activities. Additionally, November and Mull (2012) pointed out that flipped class concept prepares students for the next lesson by watching videos or other materials before class and encourage students' engagement and participation. Teachers can create video lectures for students to watch before getting into the class which allows the most effective use of the time in the classroom and students can participate in learning activities that can be more relaxing and fun rather than listen to lecture and not be able to practice English which has many rules and can get boring from just listening to lectures. Most students view English as a subject that's hard to learn, boring, too reliance on remembering, no time to practice in daily life, etc. Academics have researched for solutions by creating innovative learning concepts that is suitable for current situation in this age of change. The concept of "Teach less but Learn more" is one of the learning concept that support problem solving that various educational institutions are using in their curriculum which allows students to learn anywhere anytime. (Bumrung Ngamkarn, 2013).

\section{Refrencess}

Academic Journal of Santaphon College, 6(1), 39-47. Retrieved from https://so05.tci-thaijo.org/ index.php/scaj/article/view/179013

Aksorn Education Public Company Limited. (2019). Flipped Classroom. Retrieved from https://www.aksorn.com/flipped-classroom-1.

Classroom. Retrieved from Web site: http://www.ccsenet.org/journal/index.php/elt

communication ability and motivation in English learning of upper secondary school students. Chulalongkorn University

fluency and coherence, lexical resource,grammatical range and accuracy and pronunciation among business Online Public Company Limited (BOL. Faculty of Humanities and Social Science; Burapha University.

Khon Kaen University Teaching Innovation Center. (2020). Flipped Classroom. Retrieved from https://ltic.kku.ac.th/home/2020/02/25/flipped-classroom/.

Kriengkrai Sakulprasertsri.(2014). Effects of an English instruction using the flipped learning approach on English oral

Kanjana Wuttisak.(2017).Using flipped classroom in teaching English in tertiary level. School of 
Liberal Arts, Sripatum University.

Mark Feng Teng.(2017).Studied the subject. The classroom was reversed to improve speaking skills of EFL students.

Ministry of Education. Basic Education Core Curriculum (2008). Bangkok: Agricultural Cooperative Association of Thailand Printing House, 2008.

Natnaree Ritthirat and Dr.Thanyapa Chiramanee. (2014). Problems and Obstacles to Developing English Speaking Skill of Thai University Students. Prince Of Songkla University, Pattani Campus. Onnicha Kobkum.(2018). Salesperson personality development. Retrieved from

Nuttaya Hoonnoi (2018). the problems and English speaking abilities and compare the English speaking abilities of

Zhang, Fan. (2017). Quality-Improving Strategies of College English Teaching Based on Microlesson and Flipped

Pattaratip - Thongwas. (2019). The development of teaching activities in conjunction with the learning management

process in the classroom is reversed. To develop listening and speaking English skills of Mathayom Suksa 2

https://sites.google.com/site/karphathna104/khwam-hmay-khxng-kar-

ud?fbclid=IwAR1on8tVEcpWGX7tRXzd_QQELF2SCkiJosO7UtmMSVDvNe0NiWU78RWbv $1 \mathrm{~g}$.

Pimpawee Suwanno. (2017). Conducted an experimental study on The results of using the classroom teaching model

Rattana Buason. (2011). Research and Development of Educational Innovations. Second printing. Nakhon Sawan: Rimping Printing.

Surachai Chokkanchit Thai. "Coronavirus Outbreak 2019 (COVID 19)” (17 September 2021). Retrieved from https://he01.tcithaijo.org/index.php/JPMAT/article/view/242185/164693were reversed with researchbased learning. of 4 year students, Yala Rajabhat University.

Suchaya Poomsuay. (2016). Conducted an experimental study on Development of computerassisted English

vocabulary lessons for Grade 3 students at Chonburi School. Silpakorn University.

Gülsüm Asiksoy and Fezile Ozdaml. (2017). The Flipped Classroom Approach Based on the 5E Learning Cycle Model

- 5ELFA. ournal of Education-Hrvatski Casopis za Odgoj i obrazovanje.

Students are more satisfied with the inverted teaching method. Beijing Normal University, Zhuhai, China.

Zhang, Fan (2017) Improving the quality of college teaching English using a reverse classroom teaching model. Central South University. 